\title{
Prevalence and sustainable control of Balantidium coli infection in pigs of Ranchi, Jahrkahnd, India
}

\author{
R K Bauri*12, Rajeev Ranjan², A R Deb ${ }^{1}$ and R Ranjan ${ }^{3}$ \\ 1. Department of Veterinary Parasitology, 2. Project Directorate on Foot and Mouth Disease, \\ IVRI Campus, Mukteswar - 263138, Naninital, Uttarakhand. 3. Department of Animal Nutrition, Ranchi \\ Veterinary College, B A University, Ranchi-834006, J harkhand. \\ *Corresponding author email- drrkbauri@gmail.com \\ Received: 11-08-2011, Accepted: 13-09-2011, Published Online: 01-12-2011 \\ doi: $10.5455 /$ vetworld.2012.94-99
}

\begin{abstract}
Pigs had a higher degree of gastrointestinal protozoa infection 93 out of 100 faecal samples. Balantidium coli infected pigs were controlled effectively by oxytetracycline ( $100 \%$ on $3^{\text {rd }}$ day of observation) and Metronidazole + Furazolidone combination ( $100 \%$ on $5^{\text {th }}$ day of observation). Initially B. coli infected pigs had decreased haemoglobin, pack cell volume and total erythrocyte count values, but these pigs returned towards normal ranges after $7^{\text {th }}$ day of observation. The differential leukocyte count values of $B$. coli infected pigs showed decreased values of neutrophils, and lymphocytes, and increased eosinophils values come towards normal range on $7^{\text {th }}$ day of observation. The average body weight gain in oxytetracycline and metronidazole + furazolidone combination treated Tampworth \& Desi piglets showed higher viz.35.25 $\pm 1.64 \mathrm{~kg}$ and $28.08 \pm 1.75 \mathrm{~kg}$ of body weight respectively than untreated infected control piglets $(15.75 \pm 2.39)$. The average body weight gain in Oxytetracycline and metronidazole + furazolidone combination treated desi piglets were higher body weight viz. $36.67 \pm 1.07 \mathrm{~kg}$ and $32.50 \pm 0.96 \mathrm{~kg}$ respectively than untreated infected control piglets $(22.00 \pm 0.88 \mathrm{~kg})$. In both the treatment group, the group treated with Oxytetracycline had significantly higher body weight gain $35.25 \pm 1.64$ $\mathrm{kg}$ and $36.67 \pm 1.07 \mathrm{~kg}$ in both $\mathrm{T} \& \mathrm{D}$ and desi piglets respectively than metronidazole +furazolidone combination treated $\mathrm{T} \& \mathrm{D}$ and desi piglets $(28.08 \pm 1.75 \mathrm{~kg}, 32.50 \pm 0.96 \mathrm{~kg}$ respectively). The observation on different hematological parameters during $B$. coli infection and their treatment indicated that the harm caused by $B$. coli in pigs could be reduced to a greater extent by suitable therapeutic management. Application of suitable control packages were found to be very encouraging for maintaining optimum health and economical pig production. Oxytetracycline drugs showed higher efficacy than metronidazole + furazolidone combination and it show significantly higher growth in body weight in both $T \& D$ and desi piglets.
\end{abstract}

Key words: Pig, B. coli, prevalence, control, Oxytetracycline.

\section{To cite this article :}

Bauri RK, Ranjan R, Deb AR and Ranjan R (2012): Prevalence and sustainable control of Balantidium coli infection in pigs of Ranchi, J ahrkahnd, India, Vet. World 5 (2): 94-99, doi: 10.5455/vetworld.2012.94-99

\section{Introduction}

The common zoonotic gastrointestinal protozoa are Giardia spp, Entamoeba spp, Toxoplasma spp., Sarcocystis spp, Balantidium spp and Cryptosporidium $\mathrm{spp}$ which are usually communicable to man and animal and vice-versa. The various domesticated animal suffer from zoonotic disease which are easily transmitted to man (Takanomeron, 1971). These protozoa are highly prevalent in rural and urban population of tropical and subtropical countries (Grewal, 1968 and Rao et $a l, 1975)$.

The infection is very frequent in swine, prevalence rate $60-90 \%$ have been reported in animals in single herd. In man, it is most often found in individuals who were in contact with swine and those exposed to poor environmental hygienic condition. Disease of B. coli in man usually affects the mucosa of the large intestine, but it can also invade the liver and the lungs, though it rarely happens (Vidan et al.1985; Ladas et al., 1989). Keeping in view the above facts, the present was done to know the prevalence and sustain the control of $B$. coli infection in pigs.

\section{Materials and methods}

Prevalence of B. coli infection in pigs: The 
Prevalence and sustainable control of Balantidium coli infection in pigs of Ranchi, Jahrkahnd, India

Table-1. Drugs administration schedule against B. coli infection in T\&D and Desi pigs

\begin{tabular}{|c|c|c|c|c|}
\hline Groups & $\begin{array}{l}\text { Number of } \\
\text { animals }\end{array}$ & Drugs trial & $\begin{array}{l}\text { Day of } \\
\text { treatment }\end{array}$ & Period of observation (days) \\
\hline $\begin{array}{l}\text { Infected } \\
\text { and treated }\end{array}$ & 6 & $\begin{array}{l}\text { Metronidazole } 20 \mathrm{mg} / \mathrm{kg} \text { body wt. + } \\
\text { Furazolidone } 10 \mathrm{mg} / \mathrm{kg} \text { body wt.(Fazole } \AA) \\
\text { orally daily for } 4 \text { consecutive days }\end{array}$ & 4 days & $\begin{array}{l}\text { 'O' day,3rd day,5th day,7th day,9th } \\
\text { day,11th day, } 15 \text { th day then weekly } \\
\text { interval up to 90th day. }\end{array}$ \\
\hline -do- & -do- & $\begin{array}{l}\text { Oxytetracycline @ } 10 \mathrm{mg} / \mathrm{kg} \text { b. wt. orally } \\
\text { daily for } 4 \text { consecutive days }\end{array}$ & -do- & -do- \\
\hline $\begin{array}{l}\text { Infected } \\
\text { control }\end{array}$ & -do- & Untreated $\quad$ group (control) & ----- & -do- \\
\hline $\begin{array}{l}\text { Healthy } \\
\text { control }\end{array}$ & -do- & -do- & ----- & -do- \\
\hline
\end{tabular}

prevalence of Balantidium coli in pigs estimated by the faecal samples (100) taken directly from the rectum from Institute's farm and field. The individual faecal sample collected in plastic container with tight lid or closed plastic bags were brought to the laboratory for examination. Each faecal sample was examined by direct and indirect method described by Soulsby (1982). Prevalence B. coli were identified on the basis of cysts and trophozoites morphological features (Soulsby, 1982; Chatterjee, 1996).

Therapeutic management of $B$. coli infecting T\&D (Cross breed of Tamworth and Desi pigs) and desi pigs: For the control of $B$. coli in pigs, 18 naturally infected T\& D and 18 desi piglets of almost similar age groups were selected and maintained at piggery unit, Ranchi Veterinary College on normal balanced feeds ad libitum. The animals were divided into three groups having six animals each. $1^{\text {st }}$ group was treated with Metronidazole @ 20mg/kg body wt. +Furazolidone @ 10mg/kg b. wt. orally for 4 consecutive days, $2^{\text {nd }}$ group was treated with Oxytetracycline@ 10 $\mathrm{mg} / \mathrm{kg} \mathrm{b}$. wt orally for 4 consecutive days and $3^{\text {rd }}$ group remained infected with B.coli (control). Another healthy group was taken for comparison with these groups and it was kept in $4^{\text {th }}$ group which was uninfected and untreated. Any other erroneous infections were therapeutically managed. The detail therapeutic trials in T \& D breed and desi pig were carried out as per the experimental schedules mentioned in the table 1 . Observations of treatment were recorded as per the schedule follow:

i) Pre and post treatment Cyst per gram (CPG) twice weekly up to $15^{\text {th }}$ day post treatment
(DPT) and, then, fortnightly up to 90 days.

ii) Haematological observations ( $\mathrm{Hb}, \mathrm{PCV}$, TEC and DLC) on 0 day before treatment and then weekly intervals up to 30 days.

iii) Growth rate at fortnightly interval.

Estimation of cyst per gram (CPG): The CPG of each animal infected with $B$. coli was estimated before and after treatment, twice weekly upto $15^{\text {th }}$ day and, then, fortnightly upto the end of experiment as per Stoll dilution method (1930). The percent efficacies of the drugs were calculated by the formula:

Percent Efficacy $=$ Pre treatments mean CPG - Post treatments mean CPG / Pre treatments mean CPG X 100.

Haematological observations: For assessing different hematological parameters, the blood was collected from anterior vena-cava in small sterile vial having anticoagulant EDTA @ 1-2 $\mathrm{mg} / \mathrm{ml}$ of blood. The hematological parameter Viz. Hemoglobin ( $\mathrm{g} \%)$, Packed cell volume (\%),were examined with the help of automated hematological analyzer (Transasia, Japan), Total Erythrocytes Count $\left(\mathrm{mm}^{3}\right)$ method described by Schalm et. al. (1975) as well as by using automated cell counter (Transasia, Japan), Differential Leucocytes Count (DLC) method described by Schalm et. al. (1975).

Growth rate: The growth rate in piglets during infection and simultaneous treatment in different groups were recorded fortnightly upto 90 days. For taking the gross live weight, the pigs hind legs were tied with the help of a nylon rope by attaching the body on the brisket and belly position and then, hanged to a spring balance already fitted in 
Table-2. Average body weight gain $(\mathrm{kg})$ in growing $T \& D$ piglets during $B$. coli infection in different treatment groups

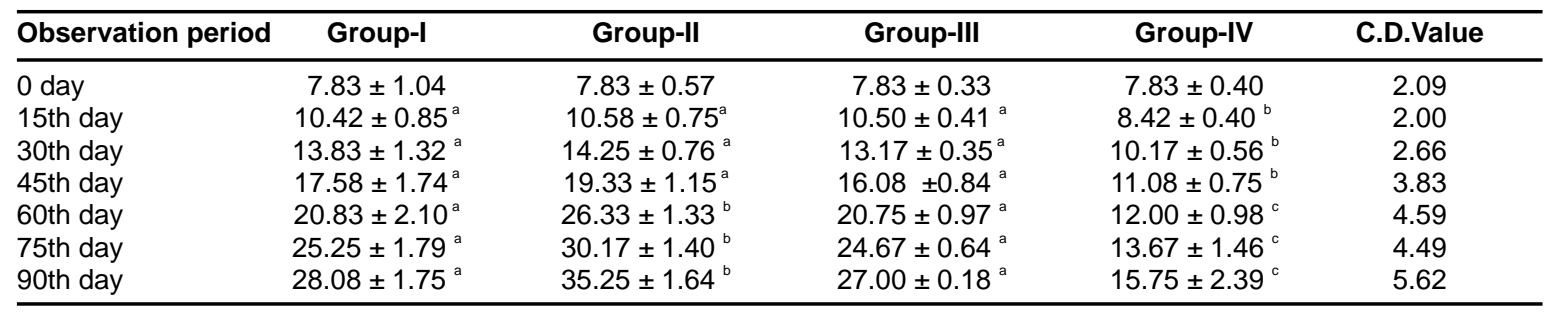

Group-I Fazole treated, Group-II Oxytetracycline treated, Group-III Healthy control, Group-IV Infected control Figures having same superscripts did not differ significantly $(P<0.05)$

the ceiling of the animals shed (Kumari, 2001).

Statistical analysis of the data collected during the study of different parameters was done by using standard formulae and methods described by Snedecor and Cochran (1994).

\section{Results and Discussion}

Prevalence of B. coli infection in pigs: Over all prevalence of Balantidium coli infection in pig both $\mathrm{T} \& \mathrm{D}$ breed as well as desi pigs were found 93\% (Chakraborthy et al., 2001, Heitman et al. 2002, Senler et al. 2003 Sturdee, 2003) by examining 100 faecal samples from T \& D breed as well as desi pig. T \& D breed of pig showed less prevalence while desi pigs showed high prevalence of incidence of $B$. coli. This desi pigs showed higher degree of gastrointestinal protozoal infection mainly $B$. coli because of poor managemental conditions adopted in most of the organized and non organized farm.

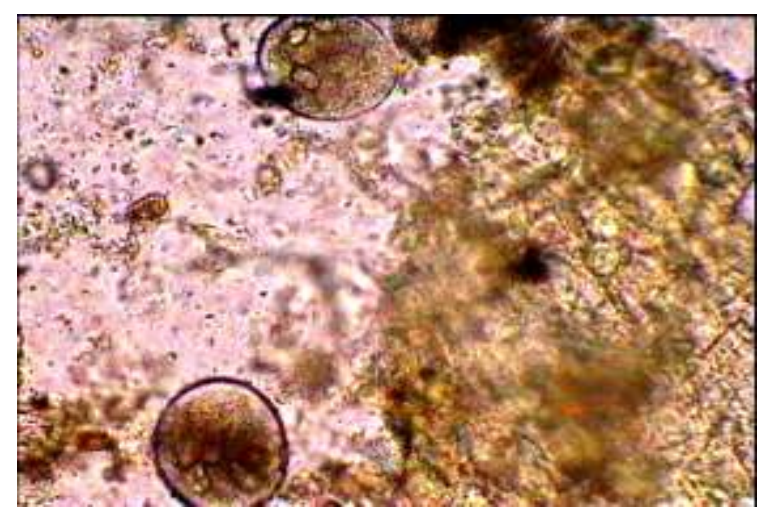

Control of B. coli infection in pigs: The growing piglets having naturally acquired $B$. coli infection were selected for their control so that considerable economic losses could be minimized to some extent. The therapeutic efficacies of Metronidazole + Furazolidone (Fazole ${ }^{\circledR}$ ) and Oxytetracycline against naturally $B$. coli infected T\&D and desi piglets were assessed. The first group which comprised of $\mathrm{T} \& \mathrm{D}$ and desi growing piglets having natural $B$. coli infection was treated with Metronidazole + Furazolidone $\left(\right.$ Fazole $\left.{ }^{\circledR}\right)$ and $2^{\text {nd }}$ group of infected piglets treated with Oxytetracycline. Animals of both the treated groups were completely free from parasites on $5^{\text {th }}$ day of treatment and $3^{\text {rd }}$ day of treatment respectively. The results indicated that both the drugs were found to be highly effective against $B$. coli infection. If the results of $B$. coli treatment of pigs were compared with the earlier findings, it was evident that the present investigation was in general agreement with the reports of Patnaik et al ,1965; Mwamba et al., 1977; Palanivel, 2005 and Sengar et al., 2006. The perusal of literature indicated that only limited references were available for the control of $B$. coli in pigs. Hence, there is a need to carry out similar trials of control of $B$. coli on large population of pigs of different age group under different farm condition for confirming the results of the present study. All the growing piglets of both the treated groups were examined time to time at regular interval after first treatment and the natural re-infections acquired on $30^{\text {th }}$ days were treated with respective drugs to control the infection as per the schedule showed in table 1.

Haematological observation during B. coli infection and their treatment: Haematological profiles of growing desi and T \& D piglets during $B$. coli infection and their treatment was carried 
Table-3. Analysis of variance of Average body weight gain in growing $T \& D$ piglets during B. coli infection in different treatment groups

\begin{tabular}{lccc}
\hline Observation period & \multicolumn{2}{c}{ Mean square } & F Value \\
\cline { 2 - 4 } & Between groups d.f.(3) & Error d.f.(20) & \\
\hline 0 day & 00 & 3.02 & $\mathrm{NS}$ \\
15th day & 6.54 & 2.76 & $2.37^{*}$ \\
30th day & 20.45 & 4.89 & $4.18^{*}$ \\
45th day & 75.59 & 10.10 & $4.49^{* *}$ \\
60th day & 210.73 & 14.53 & $14.51^{* *}$ \\
75th day & 291.09 & 13.87 & $20.99^{* *}$ \\
90th day & 389.76 & 21.75 & $17.92^{* *}$ \\
\hline
\end{tabular}

Table-4. Average body weight gain $(\mathbf{k g})$ in growing desi piglets during B. coli infection in different treatment groups

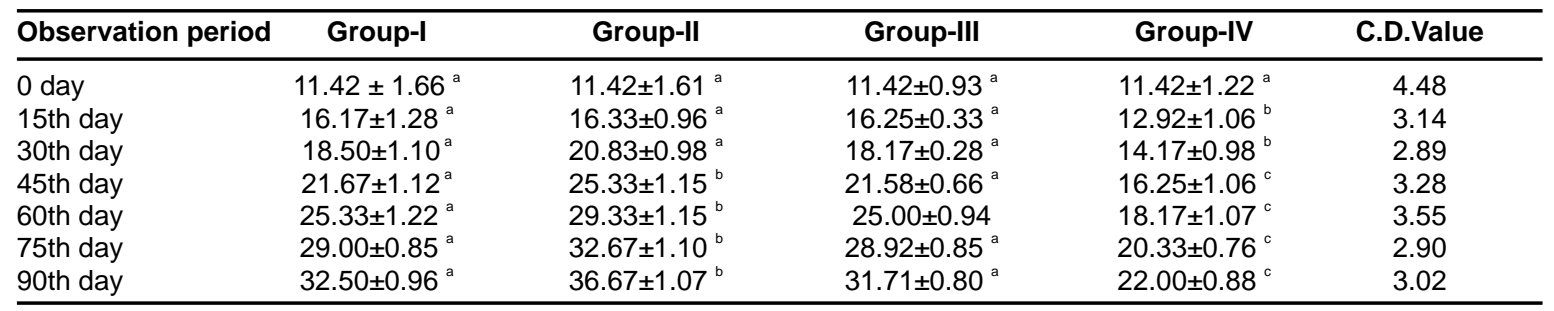

out to monitor the health status of infected and treated animals. The observation on hematological parameters also indicated that $B$. coli may cause significant decrease in the values of $\mathrm{Hb}, \mathrm{PCV}$, and TEC value. B. coli potentially to invade tissue, it penetrates the mucosa with cellular infiltration in the area of the developing ulcers. Abscess formation may extend up to muscular layer also (Garcia, 2001). Penetration of B. coli cause damage of mucosal cells leading to cause balantidial dysentery but it occurs in severe cases. But in chronic cases it may cause reduction of $\mathrm{Hb}$, PCV and TEC value. After treatment these values were found to return almost the normal ranges this might have been taken place due to elimination of the G.I. parasites by the drugs. The marked reduction in $\mathrm{Hb}, \mathrm{PCV}$ and TEC value in $B$. coli infection in pigs were also suppose to have occurred due to the suppressive effect of toxic substances secreted or excreted by B. coli.

The presents findings also indicated that eosinophils cell are increased and other cell are decreased before treatment which was found to return almost towards the normal ranges on different days of post treatment observations. Eosinophils are thought to be function mainly defense against certain types of infectious agent.
Eosinophils express receptor for a class of antibody called $\operatorname{IgE}$ and are able to bind avidity to IgE coated particles. They are particularly effective at destroying infectious agents that stimulate the production of IgE, such as helminths parasites. In fact, helminths may relatively resistant to the lysosomal enzyme of neutrophils and macrophages, but are often killed by the specialized granule protein of eosinophils. Eosinophils are also abundant at the site of immediate hypersensitivity (allergic reaction). The growth and differentiation of eosinophils are stimulated by a helper $\mathrm{T}$ cell derived cytokine called IL5 and T-cell activation contributes to eosinophils accumulation at sites of parasitic infection and allergic reaction (Abbas etal,1998).

Since, there was lack of literature mentioning the reasons for variation in hematological parameters during $B$. coli infections and their treatment with chemical drugs in pigs. However, the effects of G.I. parasitism and therapeutic management on the hematological parameters were studied and reported by Das and Prasad (2004) in goats the possible reason for the reduction in hematological constituents might due to blood loss caused by the parasites and at the same time toxic substances released by the 
Table-5. Analysis of variance of Average body weight gain in growing desi piglets during B. coli infection in different treatment groups

\begin{tabular}{lccc}
\hline Observation period & \multicolumn{3}{c}{ Mean square } \\
\cline { 2 - 3 } & Between groups d.f.(3) & Error d.f.(20) & $0.00^{\text {NS }}$ \\
\hline 0 day & 0.00 & 13.87 & $2.45^{*}$ \\
15th day & 16.69 & 6.81 & $7.96^{* *}$ \\
30th day & 45.94 & 5.78 & $11.28^{* *}$ \\
45th day & 83.90 & 7.44 & $14.81^{* *}$ \\
60th day & 128.82 & 8.70 & $28.34^{* *}$ \\
75th day & 164.20 & 5.79 & $36.79^{* *}$ \\
90th day & 231.09 & 6.28 & 3 \\
\hline
\end{tabular}

parasites would have caused the suppressive effects on haemopoesis as these parameters were observed to have returned at about normal ranges when the parasites effects were removed by the treatment with suitable drugs.

Body Weight gain in growing piglets: For assessing, the economic impact of B.coli infection and their control in pigs. The gross weight $(\mathrm{kg})$ gain in growing piglets during $B$. coli infection and their treatment were estimated by recording the $b$. wt. gain in growing $\mathrm{T} \& \mathrm{D}$ and desi piglets for about a period of 90 days (table 2, 3, 4 and 5). The total gross weight gain by Metronidazole + Furazolidone treated group and Oxytetracycline treated T \& D pigs were $168.5 \mathrm{~kg}$ and $211.5 \mathrm{~kg}$ respectively while it was $162 \mathrm{~kg}$ in healthy group. The total gross weight gain by Metronidazole + Furazolidone treated group and Oxytetracycline treated desi pigs were $195 \mathrm{~kg}$ and $220 \mathrm{~kg}$ respectively while it was $119.3 \mathrm{~kg}$ in healthy group.

The present findings indicated that growth of Tetracycline treated group animals was more in respect to Metronidazole + Furazolidone treated group. More growth rates in Oxytetracycline therapy was not clearly known but it may be due to broad spectrum activity of Oxytetracycline which checks the other microbes present in gastrointestinal tract resulting into increased feed intake, feed utilization and increased absorption of nutrients. (Horvath et al, 1954; Castillo et al., 2003; Michalova et al., 2004).

\section{Acknow ledgement}

The authors are grateful to the Dean, Ranchi Veterinary College and the Vice-Chancellor of BAU, Ranchi for necessary facilities and funds.

\section{Conflict of interest} interest

Authors declare that they have no conflict of

\section{References}

1. Abbas, A.K., Lichtman, A.K., and Pober, J.S. (1998).Celluler and moleculer technology.3rd edition.pp-27.

2. Castillo, J.D. (2003). Short-term effects of infeed supplementation of tetracyclines for disease control on feed intake pattern and growth in weaned pigs. Livestock Production Science, 76(1-2) : 115 .

3. Chakraborty, A. and Goswami, P.K. (2001). Parasites of non human primates of Assam State zoo. J. Vet. Parasitol., 15 (2): 121-124.

4. Chatterjee, K.D. (1996). Parasitology in relation to clinical medicine,Twelth edn.,Kolkata

5. Das, M. and Prasad, K.D.(2004). Haematolpgical observation in G.I. nematode infected and anthelmintic treated goats. J. Res, BAU.16 (2): 329-331.

6. Garcia ,L.S.(2001). Diagnostic of medical parasitology. $4^{\text {th }}$ ed.pp-55.

7. Grewal, M.S. (1968). J. Ass.Physns. India,16 : 319-314.

8. Heitman, T.L., Frederick, L.M., Viste, J.R., Guselle, N.J., Morgan, U.M., Thompson, R.C.A. and. Olson ,M.E. (2002). Prevalence of Giardia and Cryptosporidium and characterization of Cryptosporidium spp. isolated from wildlife, human, and agricultural sources in the North Saskatchewan River Basin in Alberta, Canada. Can. J. Microbiol. 48(6): 530-541.

9. Horvath, D. J. and Noot,G. W. V.(1954). Effect of Three Levels of a New Antibiotic, Tetracycline, in a Swine Ration. J. Anim Sci. 13 : 899-903.

10. Kumari, S.(2001).Studies on the incidence and 
therapeutic control of gastrointestinal parasites and their impact on the economics of pig production. M.V.Sc. Thesis.B.A.U.,Ranchi. India pp.1-79.

11. Ladas, S.D., S. Savva, A. Frydas, A. Kaloviduris, J. Hatzioannou, S. Raptis (1989). Invasive balantidiasis presented as chronic colitis and lung involvement.Dig Dis Sci 34 ; 1621-1623.

12. Michalova, E., Novotna, P. and Schlegelova, J. (2004). Tetracyclines in veterinary medicine and bacterial resistance to them. Vet. Med. - Czech, 49(3) : 79-100.

13. Mwamba T, Pandey VS (1977). Effect of Terramycin in balantidiosis of pigs. Ann. Rech. Vet.; 8 (2): 167-169.

14. Palanivel, K.M., Thangathurai, R. and Nedunchellian, S. (2005). Epizootology of $B$. coli infection in ruminants. Indian Vet. J., 82: 682-683.

15. Patnaik,K.B.(1965)(1965).Clinical symptoms and treatment of balantidial infection in cattle and buffaloes. Indian Vet.J. 42 : 624-632

16. Rao, C. K., Biswas, H.and Gupta, S. R. (1975) J. Com. Dis., 7 : 1-14.

17. Schalm, O. W.;Jain, N. C. and Carrol, F. J. (1975). Veterinary haematology,3rd Edn.Lea and Febiger,Philadelphia,pp.1-778.

18. Sengar.Y.S. and Singh,V.,(2006).Comperative therapeutic efficacy of Tetracycline $\mathrm{HCl}$ and
Metronidazole plus Furazolidone against B.coli infection in buffalo calves. J. Vet. parasitol.,20 (1) : 89-91.

19. Senlar, N.G. Gul, A. and Deger, S. (2003). Prevalence of endoparasites in dogs and their importance on human health in and around VAN.Indian Vet.J.,80:832-833.

20. Snedecor, G. W. and Cochran, W.G. (1994).Statistical methods, $7^{\text {th }}$ edn. Oxford and IBH Publishuing Co., New Delhi.

21. Soulsby, E. J. L. (1982) Helminths, Arthropods and Protozoa of Domesticated Animals.7th edn. (ELBS) Bailiere Toindal, London,p.809.

22. Stoll, N. R. (1930).Investigation on the control of hookworm disease. An effective method of counting hook worm eggs in the faeces. Am.J.Hyg., 3 : 59-60.

23. Sturdee, A.P., Bodley-Tickell. A.T., Archer A. and Chalmers, R.M. (2003). Long-term study of Cryptosporidium prevalence on a lowland farm in the United Kingdom.. Vet.Parasitol, 116(2): 97-113.

24. Takano-meron,J.(1971).Giardiasis.In; Pathology of protozoal and helmintic diseases, (R.A. Marcial.Rajas ,ed.) pp.115-123 Williams and Wilkines Baltimore Maryland.

25. Vidan, J. R.,A. Frauca, B. Martiinez, F. Borda (1985).Parasitosis hepatica por Balantidium coli.Med Clin (Barc) 85 : 299-300. 